\title{
FÜLEKY GYÖRGY (1945-2018)
}

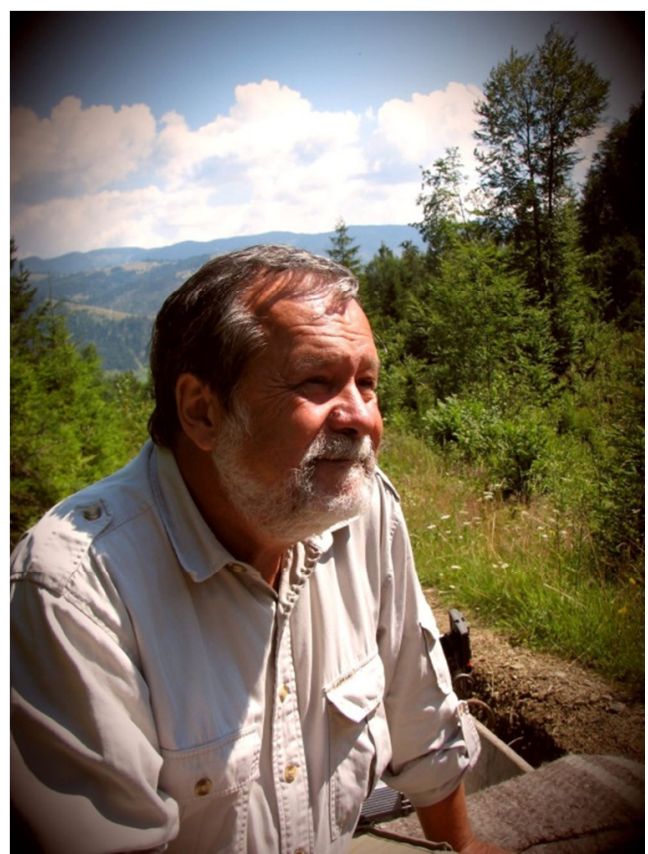

2018 május 4.-én elhunyt Füleky György a Szent István Egyetem Széchenyi Professzori Ösztöndíjas professor emeritusa, a mezőgazdasági tudományok kandidátusa.

Füleky professzor úr 1968-ban okleveles kémia-fizika szakos tanárként végzett az Eötvös Lóránd Tudományegyetemen, szakmai pályafutását a Magyar Tudományos Akadémia Talajtani és Agrokémiai Kutató Intézetében kezdte. Oktatói és tudományos tevékenysége 1983-tól a Szent István Egyetemhez (illetve jogelödjéhez, a Gödöllői Agrártudományi Egyetemhez) kötődött.

Professzor úr magyar és angol nyelven oktatott a képzések minden szintjén, graduális, posztgraduális, doktori és szakmérnöki képzéseken. A kezdetektől részt vett a Szent István Egyetem vezetői és oktatásszervezői munkájában is. A rendszerváltás idején az egyetemi autonómia kérdéseivel foglalkozó bizottság elnökeként oroszlánrészt vállalt a zökkenőmentes váltás előkészítésében oktatási, szervezési és egyéb területeken, valamint az új oktatási rendszer alapjainak lerakásában. A Szent István Egyetem rektorhelyetteseként irányította az egyetemi oktatási-minőségbiztosítási rendszer kialakítását, az évente megjelenő és a teljes tantárgyválasztékot bemutató Oktatási Almanach kiadását. Létrehozta az öntevékeny egyetemi művészeti és kulturális életet szervező Kulturális Missziót. 
Professzor úr kimagasló oktatói és kutatói munkája mellett mindenkor fokozott érdeklődéssel fordult az egyetemtörténeti, szakmatörténeti kérdések felé. Számos videó-interjúban szólaltatta meg a jelentős szerepet játszó professzorokat, tudós személyiségeket. Az intézménytörténeti szempontból pótolhatatlan felvételek elkészítése mellett meghatározó szerepet vállalt a GATE történetét a mai napig legteljesebben feldolgozó jubileumi emlékkönyv összeállításában, az egyetemtörténeti emlékek összegyüjtésében, amelyért Kosáry Domokos-díj elismerésben részesült.

Egyetemi tevékenysége mellett tagja volt az MTA Talajtani-, Vízgazdálkodási és Növénytermesztési Bizottságnak és az Agrokémia és Talajtan folyóirat Szerkesztőbizottságának. Alapító főszerkesztője volt az Egyetem angol nyelvü tudományos kiadványának, a Bulletin of the University of Agricultural Sciences, Gödöllö, majd annak jogutódja a Bulletin of the Szent István University, Gödöllő címü kiadványnak.

Füleky professzor úr szakterületének, az agrokémiának és több társtudománynak, különösen a régészeti talajtannak, megbecsült képviselője volt. Kutatási tevékenységében egyaránt megtalálhatók voltak az alapkutatások, az alkalmazott kutatások és a módszertani fejlesztések. A talajokkal kapcsolatos kutatómunkája egyaránt irányult a talajra, mint természeti képződményre, a benne végbemenő folyamatok minél alaposabb megismerésére, a mezőgazdasági termelés alapelemére, termékenységének megőrzésére és fokozására, valamint a talajra, mint természeti és kultúrtáji környezetünk részére.

Professzor úr számos szakmai társaság és bizottság vezető tisztségviselője volt.

A Szent István Egyetemen eltöltött 35 éve alatt kiemelkedő szaktudásával és elkötelezett munkájával kivívta nem csak munkatársai, hanem mind a hazai, mind a nemzetközi szakmai szervezetek elismerését. Kiemelkedő munkásságáért számos szakmai és tudományos kitüntetésben, kiadói nívódíjban részesült.

Mi, akik Füleky professzor úr tanítványai, később közvetlen munkatársai lehettünk, és ezáltal tanítását, a szakmához, az emberekhez való hozzáállását még mélyebben élhettük és érthettük meg, életünk végéig fogjuk emlékét örizni.

Nagyon sokat tanultunk a professzor úrtól a vele együtt alapított képzések, szakok, hazai és nemzetközi szakmai szervezetek révén, de azokon a konferenciákon, szakmai utakon is, amelyeken együtt vettünk részt, és ahol ő mindig a rá jellemző derüvel, életszeretettel és a másoknak adás szeretetével vett részt.

Professzor úr megtanította nekünk, hogy mit jelent a gyakorlatban az interdiszciplinaritás, átadta a tudomány és a szakma szeretetét, megértettük, hogy mit jelent a mindennapokban az, hogy elhivatottság és bizonyította számunkra a sokrétüség fontosságát.

Professzor Úr emléke örökké szívünkben él! 